\title{
Uncommon Knowledge: World Bank Policy and the Unmaking of the Knowledge Economy in Africa
}

\author{
Milton O. Obamba
}

Centre for Higher Education Policy Research, Leeds Metropolitan University, Beckett Park Campus, Leeds LS6 3QS, UK.

E-mail: m.o.obamba@leedsmet.ac.uk

The World Bank is clearly one of the most influential global intergovernmental operators for international development assistance. In recent decades, the Bank and other agencies have invested immense technical and financial resources in a troubled and unprecedented mission of revitalizing and restructuring the development of education in Africa. A growing body of critique has emerged that articulates the failures of the revitalization mission, framing these exchange relationships as representing nothing but new patterns of embedded neocolonialism, dependency, and geopolitical asymmetry. The aim of this paper is to contribute to and disrupt these unfolding debates by examining how a set of theoretical paradigms have shaped the World Bank's priorities and approaches to education and development policy in developing countries at different times. The paper argues that the Bank embraced the neoliberal economic ideology and a narrowly defined interpretation of the "rates of return' calculations to promote higher investment in basic education while systematically marginalizing higher education. The paper asserts that this polarized policy paradigm persisted within the Bank at least until the 1990s and has partly fuelled the preponderance of the critiques of neo-colonial dependency and hegemony. This paper opens a new analytic territory by examining the coordinates of two recent and increasingly significant World Bank policy paradigms: the 'innovation systems' and 'global partnership' approaches.

Higher Education Policy (2013) 26, 83-108. doi:10.1057/hep.2012.20; published online 28 August 2012

Keywords: World Bank; human capital; knowledge economy; international development; sub-Saharan Africa; education policy

\section{Introduction}

The higher education development and policy landscape in sub-Saharan Africa has been reconfigured and influenced by external agencies and forces for many decades. The evidence suggests that the World Bank is by far the largest and most powerful intergovernmental provider of various forms of programme 
lending and technical assistance for educational development in developing countries, including sub-Saharan Africa (World Bank, 2009a). In FY2009, for example, the sub-Saharan region received US\$720 million in education lending, making it the second largest recipient of Bank lending for education after the Caribbean (World Bank, 2009b). The use of programme lending instruments combined with the Bank's remarkable research infrastructure and dissemination capabilities demonstrate the dominant power of the World Bank in framing the global development agenda and the trajectories of development policy (Samoff and Carrol, 2004; Teferra, 2010; Obamba, 2011, 170-175).

However, a growing body of recent critique has framed the complex relationship between the Bank and developing countries as representing the reproduction of neo-colonialism and dependencies embellished as neoliberal ideology (Sidhu, 2007; Collins and Rhoads, 2010). Policy transformations and more dynamic development paradigms that have recently emerged have not been adequately highlighted in these static critiques (see Aina, 2010). The purpose of this paper is to build on and also disrupt these mainstream strands of critical discourse on African education and development policy. The distinctiveness of this paper resides in its departure from the dominant conceptual frameworks of 'neocolonialism' and 'dependency'. Instead, it embraces a broader and more progressive analytic approach that seeks to examine the complex trajectories through which particular theoretical paradigms, including human capital theory, manpower forecasting approach, and the rate of return econometrics, emerged and became firmly embedded within the broader global economic and geopolitical order.

Focusing on the World Bank as a dominant global resource and policy system, the paper analyses how particular theoretical paradigms and perspectives have shaped the Bank's shifting priorities and approaches to education and development policy in developing countries in recent decades. The paper captures and interrogates some of the most dramatic transformations in World Bank policy: from valorization of basic primary schooling to the emphasis on the knowledge-based economy (World Bank, 2002a); from the fragmented sectoral approach to the holistic systems approach to education policy (World Bank, 2005, 2011a); from the focus on gross enrolment statistics to a focus on learning outcomes (World Bank, 2011a); and the recent tendency towards dismantling traditionally entrenched public-private and formal-informal dichotomies in education policymaking and conceptualization (World Bank, 2011a).

Building upon some of the major recent analytical works (such as Samoff and Carrol, 2004; Aina, 2010; Basset and Maldonado-Maldonado 2010; Collins and Rhoads, 2010), this paper distinctively captures and articulates some of the more recent policy discourses and regimes that have emerged within the wider terrain of international development and specifically within the Bank's education and development policy system. The two significant policy phenomena include 
the emergence of the 'science-technology-innovation' framework (OECD, 1997; World Bank, 2007) and the 'global partnership paradigm' in international development and scientific cooperation (OECD, 1996a; King, 2008). The paper undertakes a thematic and chronological analysis cutting through an extensive corpus of the most influential education sector policy documents that have defined the Bank's lending and analytic operations in recent decades. Using the Bank's repertoire of published literature as its key analytic coordinates and sources, this paper straddles and illuminates the entire landscape between the Bank's first education policy Memorandum (World Bank, 1963) and its most recent Education Sector Strategy 2020 (World Bank, 2011a).

\section{Troubled Encounters with Education Policy}

In the period between 1960 and the present, the World Bank has pursued multiple and often overlapping ideological persuasions and policy regimes towards education and development in developing countries (Samoff and Carrol, 2004). The Bank's policy regimes have in turn been fundamentally shaped by various theoretical and ideological paradigms that emerged and became dominant at different times. These theoretical regimes included human capital theory; manpower forecasting; and economic rate of return (Woodhall, 2008; Obamba, 2011). The application of these economic theories to shape education and development policy came with radical consequences for the Bank's many defenceless dependants. In the next section we examine the trajectories and impacts of these key theoretical strands.

\section{Human capital theory}

The concept of human capital dates back to Adam Smith's Inquiry into the Causes of the Wealth of Nations (1776). The human capital theory has fermented within academe since the 1950s (Vawda et al., 2001). However, its growing theoretical stature and transplantation into the domain of formal economic analysis of education investment is widely credited to Theodore Schultz's groundbreaking seminal paper Reflections on Investment in Man published in the Journal of Political Economy (Schultz, 1962). The theory of human capital investment was further formulated in immense detail by Gary Becker in his article Investment in Human Capital which appeared in the same journal (Becker, 1962). The human capital theory basically asserts that higher levels of investment in education translate directly into increased economic growth and productivity (Schultz, 1962). He explained that human capital approach:

Rests upon the proposition that people develop their capabilities as consumers and as producers by investing in themselves ... these 
investments turn out not to be trivial; on the contrary, they are of a magnitude to alter radically the usual measure of the amount of savings and capital formation. They also alter the structure of wages and salaries and the amount of earnings relative to income from property. (ibid., 1)

Harbison and Myers (1964) further illustrated the utilitarian value of investment in human capital and its strong connections with economic and political development. They asserted that:

The building of modern nations depends upon the development of its people and the organisation of human activity. Capital, natural resources, foreign aid, and international trade, of course, play important roles in economic growth; but none is more important than manpower. (Harbison and Myers, 1964, 6)

This indicated that economic theory has historically played a significant role in shaping the contours of debate and policy surrounding higher education for many decades (Woodhall, 2008). The human capital theory and rates of return econometrics represent the most significant contributions of economic theory to the political economy of higher education worldwide, particularly in developing countries where the money to invest in education is often severely limited (Psacharopoulos, 1981). Public management principles and tools, such as privatization, accountability, liberalization, and decentralization, have also considerably influenced the character and production of education policy in different contexts, including the patterns of resource availability and power relations within higher education (Woodhall, 2008).

\section{Rates of return econometrics}

The entry of human capital theory into World Bank practice in the 1960s can be traced to the ground-breaking writings noted above (Becker, 1962; Schultz, 1962). However, the theory first entered the World Bank basically as a conceptual framework for justifying the substantial investments in training local people on the management of infrastructure development projects supported by the Bank in developing countries (Heyneman, 2003, 1). If human capital theory provided the economic and moral basis for investing in people, then the economic rates of return was the analytic tool for determining and comparing the economic profitability of investments in education. The idea of rates of return and cost-benefit approaches in the economic analysis of educational investments had become widespread as early as during the 1970s (Thias and Carnoy, 1972; Psacharopoulos, 1973). However, the application of 
Cost-Benefit Analysis had been established earlier in the 1960s (Blaug, 1967). Blaug stated that:

The scarce resources available for education in each country should be husbanded according to a scale of priorities which reflect, however crudely, the estimated costs and expected benefits of educational projects. By benefits we mean the productivity of educated people. (Blaug, 1967, 40)

\section{Human Capital Theory: Global Flows and Impacts}

During the 1960s, a growing body of influential empirical and conceptual analyses emerging within human capital theory consistently showed the positive impacts of education on productivity and economic development (Schultz, 1962; Harbison and Myers, 1964). These early empirical analyses had provided a robust economic and moral basis for greater public financial investment in education to promote human capital development. In Britain, the Robbins Committee (1963) recommended a massive expansion programme for tertiary education and concluded that there was significant economic basis for 'substantially increased public expenditure on higher education' (Robbins Committee, 1963, 207). In the United States, the Carnegie Commission (1973) reported firm recommendations for significant public funding for higher education, although the Report also argued that 'the benefits are neither all personal nor all societal, but some blend of the two' (ibid., 86).

The influence of the human capital and manpower planning paradigms penetrated into the African continent in the early 1960s and became the core basis for important policy debates and development initiatives (Samoff and Carrol, 2004). The landmark Addis Ababa Conference of African Ministers of Education (UNESCO, 1961) concluded with a vigorous development philosophy emphasizing that the education establishment, especially higher education, would play a fundamental role in social, economic, and political transformation and reconstruction of post-colonial African nations (Banya and Elu, 2001, 4). A follow-up conference held in Antananarivo, Madagascar in 1962 intensified the developmental approach to education and articulated seven functions that African universities were mandated to accomplish (see Banya and Elu, 2001, 4-5). The Lagos Plan of Action (OAU, 1980) also venerated universities as the embodiment of the highest national aspirations and political ideals, and the undisputed instrument of socioeconomic and political transformation (OAU, 1980). Most African countries domesticated these core developmental principles into their national development plans during the 1960s and 1970s (Banya and Elu, 2001; Samoff and Carrol, 2004).

Despite the immense justification for the developmental role of higher education demonstrated above, a growing body of empirical studies embedded 
Table 1 Returns to education by level and country type

\begin{tabular}{|c|c|c|c|c|c|c|c|}
\hline \multirow[t]{2}{*}{ Region/country type } & \multirow[t]{2}{*}{$(N)$} & \multicolumn{3}{|c|}{ Private returns (\%) } & \multicolumn{3}{|c|}{ Social returns (\%) } \\
\hline & & Primary & Secondary & Higher & Primary & Secondary & Higher \\
\hline Africa & (9) & 29 & 22 & 32 & 29 & 17 & 12 \\
\hline Asia & (8) & 32 & 17 & 19 & 16 & 12 & 11 \\
\hline Latin America & $(5)$ & 24 & 20 & 23 & 44 & 17 & 18 \\
\hline LDCs average & $(22)$ & 29 & 19 & 24 & 27 & 16 & 13 \\
\hline Intermediate countries & $(8)$ & 20 & 17 & 17 & 16 & 14 & 10 \\
\hline Advanced countries & (14) & NA & 14 & 12 & NA & 10 & 9 \\
\hline
\end{tabular}

Source: Psacharopoulos (1981, 329).

within the 'economic rates of return' approach started to produce contrary results. Blaug (1965) conducted the pioneering rate of return analysis for the UK and concluded that the private rates of return of higher education were twice as high as its social rates of return. Blaug therefore concluded that 'these private returns create prima facia case for charging more of the costs of higher education to its direct beneficiaries' (Blaug 1965, 230). Blaug's findings in a subsequent major monograph also questioned the presumed public economic returns of higher education (Blaug, 1967). The Carnegie Report in the United States also produced results which emphasized a mixture of both public and private benefits (Carnegie Commission on Higher Education, 1973, 86).

Thereafter, World Bank economist George Psacharopoulos also completed one of the earliest international comparisons of the economic rates of return for education (Psacharopoulos, 1973). Like Blaug (1965, 1967), Psacharopoulos also concluded that the private rates of return to higher education were higher than its public benefits, and that the public returns of primary education was considerably higher in most countries than the social returns of university education. These conclusions supported the findings of an earlier analysis of the private and public costs and benefits of education in Kenya (Thias and Carnoy, 1972). Psacharopoulos (1981) conducted another international review of empirical data from 44 countries around the world. As illustrated in Table 1, the study concluded that 'the returns to primary education, whether private or public, are the highest among all levels of education' (ibid., 326). These studies asserted that primary education was a more productive public investment compared with university education.

\section{Manpower planning: costs and benefits}

It has been suggested that the human capital theory had contributed, to some extent, to reshaping World Bank policy towards investment in education 
(Heyneman, 2003). However, some authors have argued that the entrenchment of human capital theory within academic and development circles during the 1960s did not directly shape the World Bank's initial decision to provide programme lending to education (Jones, 1992: noted in Vawda et al., 2001). Jones asserted that 'there is no evidence that senior Bank management embraced education because of new ideas about the development of human capital or human resources' (cited in Vawda et al., 2001, 2). Instead, Jones explained that World Bank thinking about education initially evolved out of its own practical experience and the realization that most developing countries lacked the skilled manpower required to administer the Bank's infrastructure development programmes (see Heyneman, 2003).

However, the Bank became aware of another significant challenge: how to determine whether existing local expertise was sufficient to manage its infrastructure projects and how much new skilled manpower should be developed. This unique challenge led the Bank to consider adopting the manpower forecasting approach to programme lending (Heyneman, 2003; Samoff and Carrol, 2004). A closely associated concern was how to determine the economic costs and profitability of investments in manpower development (Vawda et al., 2001). In the commissioned monograph mentioned above, British economist Mark Blaug had recommended to the Bank to apply the Cost-Benefit Analysis approach instead of manpower forecasting methods in evaluating education projects (Blaug, 1967, 40). This seminal monograph would exert a profound influence on subsequent empirical and macroeconomic analyses. Between 1970s and 1980s, a large and prolific body of empirical and conceptual analyses emerged from within and outside the World Bank, which emphasized that the viability of investments in education could only be justified and established by computing the costs and benefits of the projects. A large majority of emerging studies maintained that primary schooling was more profitable than university education (Psacharopoulos 1973, 1981).

\section{Policy Fragmentation and Valorization of Basic Education}

The idea that the World Bank should formulate a formal education lending policy and programme portfolio did not take root until the middle of the 1960s. This followed the publication of a memorandum on education lending policy (World Bank, 1963). The memorandum emphasized that the Bank would concentrate on supporting basic education projects in developing countries. However, the predominant focus would be on 'bricks and mortar' or infrastructure construction projects, and not on curriculum or staff development programmes (Vawda et al., 2001; Heyneman, 2003). The paradox is that university education 
was entirely ignored in this pioneering World Bank memorandum. The memorandum stated that:

In most developing countries ... the most urgent need is for (a) an expansion of vocational and technical education and training at various levels including technical schools, agricultural schools ... (b) an expansion of general secondary education to provide middle-level management for government, industry, commerce, agriculture. (World Bank, 1963)

This seminal memorandum therefore established and articulated the ideological foundations of the World Bank's hostile or indifferent approach to higher education in developing countries (World Bank, 1963). The same ideological approach was reproduced in subsequent papers: Lending to Education (World Bank, 1970); Education Sector Paper 1971 (World Bank, 1971); and Education Working Paper 1974 (World Bank, 1974). In these watershed policy documents, the Bank argued vigorously that most developing countries had erroneously 'overinvested' in higher education, while primary education and the traditional sectors based within the rural economy had been neglected. The papers affirmed that the Bank's priority in developing countries would focus on supporting basic schooling and low-cost vocational education to provide minimum manpower requirements.

The Working Paper (1974) vigorously elaborated on the importance of basic schooling for developing countries and prescribed a limited set of key priorities: promoting mass primary education, rural development, traditional economy, and transforming the overall economic approach to ensure that the benefits of national development, including education, can 'trickle down' to the poor masses. To achieve these aims, the paper proposed highly controversial policy measures. For example, the paper recommends 'rationing secondary and higher education and changing the patterns of demand for education through suitable [which means higher] pricing' (ibid., 4). In short, all the key seminal World Bank policy papers emphasized basic education and minimum levels of skilled manpower for developing countries. This paradigm gathered immense global momentum and legitimization in the 1990s through the emergence of the dominant discourses and global frameworks of 'Universal Primary Education' and 'Education for All'. More significantly, these papers laid the foundation for the systematic marginalization of tertiary education in subSaharan Africa for many decades. The Sector Paper of 1974 stated that:

The provision of minimum education is an essential condition for the effective participation of the masses in the development process. Lowcost, functional, mass education is required ... for poor countries facing serious problems in expanding primary enrolment, the concept of basic education is proposed as a more adequate approach to provide minimum learning packages. (World Bank, 1974, 5) 


\section{Peripheralization and Devaluation of Higher Education in Africa}

As we have seen, a large body of conceptual and empirical analyses during the 1960s had supported increased investment in education based on human capital theory (Schultz, 1962; Becker, 1962; Harbison and Myers, 1964). However, the ideological and theoretical landscape had shifted significantly during the 1970s and 1990s. The pioneering studies that had supported higher investment in education, including university education, had lost much of their initial ideological influence (Samoff and Carrol, 2004). Instead, the empirical studies claiming that primary education accrued the highest social returns gained greater ideological and political influence within the World Bank (Blaug, 1967; Thias and Carnoy, 1972; Psacharopoulos, 1973, 1981).

The dominant policy paradigm reflected in early World Bank papers had embraced human capital and manpower development principles. However, the interpretation and implementation of these concepts in relation to education and development policy in developing countries has been profoundly fragmented and asymmetrical. The Bank had firmly maintained that university education was not an immediate development priority for developing countries. Instead, mass primary education, low-cost vocational training, and other forms of informal education were strongly emphasized as critical for development (World Bank, 1963, 1970, 1971, 1974).

The policy of peripheralization of higher education in Africa persisted during the 1980s and intensified throughout the 1990s in shaping the Bank's approach to higher education sector in sub-Saharan Africa (Psacharopoulos, 1981; Saint, 1992). The rise of the global framework of 'education for all' contributed to a more intense political and financial focus on primary education at the expense of higher education worldwide, especially in developing countries. Numerous respected analyses emerging from within the Bank maintained that higher education in Africa was unnecessarily costly, inefficient, and deeply inequitable (Psacharopoulos, 1980, 1981; World Bank 1980; Hinchliffe, 1985). For example, the Bank's Education Sector Paper 1980 demonstrated the sustained trajectory of marginalization universities in subSaharan Africa. It stated that:

In lending to low-income countries, the emphasis will be on the development of low-cost basic education programs to meet the minimum needs for learning of school-age children and uneducated adultsespecially women. (World Bank, 1980, 87)

The ideological and political onslaught against university education in subSaharan Africa intensified and acquired a life of its own during the 1980s and 1990s. At a meeting with Vice-Chancellors of African universities held in Harare, Zimbabwe in 1986, the World Bank sensationally claimed that African 
Table 2 Trends of World Bank financing for education in sub-Saharan Africa (US\$ millions)

\begin{tabular}{lrrrrrrrrrrr}
\hline Subsector & $F Y 90$ & $F Y 91$ & FY92 & FY93 & FY94 & FY95 & FY96 & FY97 & FY98 & FY99 & FY00 \\
\hline Primary & 90.7 & 153.2 & 82.7 & 184.3 & 99.4 & 104.4 & 95.4 & 15.3 & 226.1 & 126.4 & 57.2 \\
Tertiary & 119.7 & 30.6 & 163.7 & 131.0 & 69.9 & 30.2 & 41.7 & 11.5 & 46.0 & 24.6 & 13.9 \\
& & & & & & & & & & & \\
Total Africa & 310.2 & 220.9 & 324.1 & 364.4 & 268.4 & 175.0 & 194.6 & 115.2 & 400.3 & 208.7 & 189.7
\end{tabular}

Source: World Bank (2009a, 4).

countries would be much better off if they closed down existing universities and trained their people in foreign institutions instead (Teferra, 2010, 158). A highly polemical World Bank Discussion Paper entitled Higher Education in Sub-Saharan Africa (Hinchliffe, 1985) laid out an unprecedented and devastating indictment against university education in Africa. The paper stated that university expansion was phenomenal yet the labour market for university graduates was weakening; the unit costs of university education were extremely high; and that the rising public costs of university education must be urgently transferred to students who were now seen as the direct beneficiaries. This paper, in essence, provided a detailed glimpse into the official thinking within the World Bank and the wider network of intergovernmental development agencies during the 1980s and 1990s. The dramatic decline in financial support for higher education during this period is reflected in Table 2.

\section{In the Eye of the Storm}

The period between the 1980s and the 1990s is a particularly turbulent and devastating epoch in the relatively short history of higher education in Africa. Three remarkably influential World Bank policy research publications are important in defining the substantive ideological background to the World Bank's policy approach to sub-Saharan higher education in recent years. The first document that shaped higher education policy in sub-Saharan Africa was the policy research report Financing Education in Developing Countries: an Exploration of Policy Options (World Bank, 1986). This report illustrated the rising costs and the deepening inefficiencies and inequalities that characterized the funding of education in developing countries. Anchored upon the traditional rate of return economics, the report asserts that 'the average dollar invested in primary education returns twice as much as the one invested in higher education' (ibid., 1). The report strongly emphasized a policy of transferring the public costs of higher education to the students and re-allocating government spending to the primary education sector which 
was widely believed to yield higher social returns than university education (Psacharopoulos, 1981). It also called for the development of private higher education and the liberalization and privatization of university education by withdrawing of public funding (ibid., 2).

The second key document is the 1988 policy research report Education in Sub-Saharan Africa: Policies for Adjustment, Revitalization, and Expansion (World Bank, 1988). The policy paper, drawing heavily from the 1986 analytical report (World Bank, 1986), demanded the implementation of wideranging structural reforms: drastic cutbacks in government funding for universities; promoting the growth of private universities and privately funded students; and transferring the heavy public burdens of financing higher education to students and their families (World Bank, 1988, 77). The overall policy paradigm of the structural adjustments focuses on two closely related issues: firstly, diversifying the sources of university funding; and secondly, reducing the unit costs of higher education (World Bank, 1988, 2). The paper made it clear that its recommendations will have the power to shape the relationship between sub-Saharan Africa and the global consortium of intergovernmental agencies:

This study will guide World Bank lending and technical assistance to subSaharan African education over the next several years. It should serve to provide a common ground for other donors as well. (World Bank, 1988, v)

The third key document would emerge in 1994. This policy paper, Higher Education: Lessons of Experience (World Bank, 1994), reinforced the same conditionalities and ideologies contained in the policy reports which had appeared earlier. The document reminded governments and multilateral donors of the escalating costs, economic inefficiencies, and deep social inequalities associated with public higher education provision in sub-Saharan African countries. Most significantly, this paper focused on four radical reform proposals: diversification of higher education institutions and promoting private universities, diversification of sources of funding and private income mobilization, and reduction of public expenditure on higher education. In keeping with World Bank tradition, the policy paper reproduced the rate of return arguments that had dominated public policy discourse in the 1970s and 1980 s, asserting that "within the education sector, however, there is evidence that higher education investments have lower social rates of return than investments in primary and secondary education' (ibid., 12). Borrowing heavily from the Sector Paper 1971, this more contemporary policy paper of 1994 still maintained that:

Primary and secondary education will continue to be the highest priority sub-sector in the World Bank's lending to countries that have not yet 
achieved universal literacy and adequate access, equity and quality at the primary and secondary levels. (World Bank, 1994, 12)

\section{The Hypocrisy of 'Education for All'}

From a broader perspective, the Bank's publication of Lessons of Experience (1994) demonstrated how the neoliberal ideology and the politics of marginalization of university education in developing countries had become so deeply embedded within the World Bank. Four years before the World Bank published this report, the delegates attending the World Conference on Education for All, held in Jomtien in 1990, had adopted a firm resolution whose language clearly demonstrated that all sectors of education were critical for sustainable development and must be supported. The World Declaration stated that:

Societies should ensure a strong intellectual and scientific environment for basic education. This implies improving higher education and developing scientific research, close contact with contemporary technological and scientific knowledge should be possible at all levels of education. (UNESCO, 1990, Article 8)

The adoption of Article 8 of the World Declaration of EFA had brought immense hope and optimism to most developing countries (Banya and Elu, 2001). Many expected that international donors, including the World Bank who was a co-sponsor of the Jomtien EFA Conference, would heed the global call for increased support to higher education as a critical instrument for manpower development and the anchor for achieving the EFA goals. A senior UNESCO official based in Africa (Daniba, 1991) captured this dominant perspective when he emphasized that:

We must avoid the danger of limiting ourselves to basic education and neglecting high level manpower training and research. It is not possible to solve the problems of Education for All without a national pool of expertise and without indigenous capacity for research. (Daniba, 1991, 11)

However, these great global expectations of 1990 were shattered four years down the line by the World Bank's Lessons of Experience (1994) report, which delivered a severe indictment of university education in Africa and called for a radical reduction of public funding and donor support for universities. The fragmented approach to education policy in Africa remained persistent within the World Bank and can be observed in the Education Sector Paper for 1995 (World Bank, 1995). Reproducing the traditional rate of return notions, the paper asserted that 'education, in particular primary and lower-secondary education, is critical for economic growth and reduction of poverty' (World 
Bank, 1995, 17). Like all its predecessors between the 1960s and 1980s, the 1995 paper still reproduced the same contentious conclusions:

Basic education ought to be the priority for public spending on education in those countries that have yet to achieve near-universal enrolment at the primary and lower-secondary levels. Most countries are already allocating the highest share of public spending on education to primary education. (World Bank, 1995, 4)

It is significant to recognize that the 1995 Education Sector Paper marks the last World Bank document to explicitly apply the 'rate of return' methodologies and propagate the dualistic politics of supporting 'basic education' while condemning tertiary education to the periphery in sub-Saharan Africa. This series of papers substantively represent the epicentre of the growing body of critique that has questioned the World Bank and its development policies in Africa (Samoff and Carrol, 2004; Sidhu, 2007; Teferra, 2010). A recent study (Collins and Rhoads, 2010) maintained that the World Bank's programmes and policies in developing countries represent and deepen the reproduction of new forms of global economic dependencies and geopolitical asymmetries. The next Education Sector Paper published in 1999 and the new wave of World Bank policy and analytical publications that followed seems to belong to a completely different policy trajectory and puts greater emphasis on the phenomenon of the knowledge-based economy.

\section{Knowledge Economy and Higher Education in Africa}

The discussions above indicate that the dominant ideology within the World Bank and other intergovernmental development agencies during the 1960s until the 1990s had emphasized mass basic education as the key priority for developing countries. During the latter part of the 1990s, however, major development organizations and industrialized countries began to recognize that higher education and knowledge production were critical for rapid economic development in every country. A report of the OECD, known as the Knowledge Economy (OECD, 1996b), is widely credited for pioneering and establishing the conceptual foundations of the 'knowledge economy' in contemporary development discourse. The OECD defined knowledge economies as 'economies which are directly based on production, distribution, and use of knowledge and information' (OECD, 1996b, 7).

Another significant episode in this transformation from the early notions of 'rates of economic return' to the new global paradigm of the 'knowledge economy' was the publication of the World Development Report: Knowledge for Development in 1999. This report is widely reputed for its role in deepening the 
knowledge economy by inserting knowledge production firmly at the core of development:

Knowledge is critical for development ... the balance between knowledge and other resources has shifted so far towards the former that knowledge has become perhaps the most important factor determining the standard of living - more than land, than tools, than labour. (World Bank, 1999b, 30)

The emergence of this new global knowledge paradigm resulted in the resurgence of higher education as a key instrument in driving economic growth and development around the world. As part of the unfolding of knowledge paradigm, the World Bank has undergone dramatic ideological transformations since the publication of the World Development Report in 1999. The report of a joint World Bank and UNESCO Task Force on Higher Education (World Bank, 2000) represents the clearest turning point in World Bank approach to higher education policy within the context of the knowledge economy. It asserts that:

As knowledge becomes more important, so does higher education. Countries need to educate more of their young people to a higher standard ... The quality of knowledge generated in higher education institutions ... is becoming increasingly critical to national competitiveness. (World Bank, 2000, 9)

This radical report, Higher Education in Developing Countries: Peril or Promise (World Bank, 2000), also represents an unprecedented critique of the traditional economic rates of return arguments that had buttressed the World Bank's dominant policy of promoting investment in primary education while marginalizing university education in developing countries since 1960s. This report retreated and disowned these arguments in the most categorical terms:

... narrow and, in our view, misleading economic analyses has contributed to the view that public investment in universities and colleges brings meagre social returns compared to investments in primary and secondary schools, and that higher education magnifies income inequalities.

(World Bank, 2000, 10)

In a further policy transformation, the Bank's Constructing Knowledge Societies report discussed in great detail the critical importance of knowledge and higher education in promoting development (World Bank, 2002a). In a radical departure from previous policy papers, this new World Bank report asserts that 'investments in tertiary education generate major external benefits that are crucial for knowledge-driven economic and social development' (ibid., 76). In this phenomenal report, the World Bank dramatically reversed its earlier arguments and conceded that it is doubtful that any developing country could make significant progress toward the Millennium Development goals 
related to education ... without a strong tertiary education system' (World Bank 2002a, 68). Former UN Secretary General Kofi Annan has captured this new mandate for the African universities in the knowledge-based economy:

The university must become a primary tool for Africa's development in the new century. Universities can help develop African expertise; they can enhance the analysis of African problems; strengthen domestic institutions; serve as a model environment for the practice of good governance, conflict resolution and respect for human rights, and enable African academics to play an active part in the global community of scholars. (in Bloom et al., 2005, 4)

This quotation powerfully articulates the emerging role of higher education in a knowledge-based economy. The capacity of a country to produce, adopt, adapt, disseminate, and commercialize knowledge is increasingly critical for economic competitiveness, sustained economic growth, and improved welfare of society (OECD, 1996b; World Bank, 2002a). The transition to a knowledgebased economy typically involves significant investment in four fundamental elements: a supportive policy framework, advanced skills development, a vibrant innovation system, and a strengthened information technology infrastructure (Chen and Dahlman, 2006). These four elements constitute what has been described as the Knowledge Economy Framework or the four pillars of the knowledge economy. The competitiveness of a knowledge-based economy also relies on increased connectivity and collaboration across national and disciplinary boundaries in order to mobilize diverse resources and optimize the exchange and application of knowledge (OECD, 1996a). The need for global collaboration has emerged from the realization that most problems facing contemporary society are increasingly complex, dynamic, and cross-cutting; hence no amount of research effort within one particular country or discipline or theoretical perspective can be sufficient to produce adequate or durable solutions (Obamba and Mwema, 2009, 357). Therefore, the emergence of the knowledge-based economy has evolved two significant phenomena which have helped to re-assert the importance of higher education in promoting economic growth and development. The first phenomenon is the 'partnership paradigm' in international development discourse (OECD, 1996a), and the second epoch constitutes the 'science-technology-innovations' or 'innovation systems’ paradigm (OECD, 1997; World Bank, 2007).

\section{The New 'Partnership Paradigm'}

The idea of partnership in collaborative activity is not exactly new or surprising. The UN Congress of Vienna on Science and Technology for 
Development (United Nations, 1979) for example, had discussed the basic concepts of 'participation' and 'ownership' of development programmes but in broad-brush terms. However, the establishment of the agenda and architecture of 'global partnership' as the dominant paradigm can be credited to the influential OECD report entitled Shaping the 21st Century (OECD, 1996a). In development discourse, the 'partnership' approach denotes that donor agencies work in tandem with developing countries and multiple actors while empowering them to take equal responsibility and be accountable for setting and achieving their own development goals (OECD, 1996a, 13).

Since the publication of the OECD report (1996a) the idea of global partnership has become the dominant global framework for organizing and transacting international development affairs among countries. The partnership agenda has been articulated in a growing number of recent intergovernmental instruments, including the UN Millennium Declaration (UN, 2000), Paris Declaration on Aid Effectiveness (OECD, 2005), and Accra Agenda for Action (OECD, 2008). The partnership paradigm gained prominence as a robust critique against the distortions and asymmetries embedded within the traditional 'problem-solving' approach to international development, which had emphasized the one-way transfer of financial and technical assistance from the North to the South (Velho, 2002; King, 2008).

Within higher education, the partnership paradigm is manifested as 'cooperative agreements between a higher education institution and another distinct organization to coordinate activities, share resources, and divide responsibilities related to a specific project or goal' (Kinser and Green, 2009, 4). Academic mobility and collaboration have characterized academe since medieval times. What is significant though is that, in more recent decades, the patterns, organization, political dynamics, and impacts of transnational academic cooperation and mobility have taken on increasing importance and complexity (Drake et al., 2000; Teferra, 2010). Equally unprecedented is the recent reconfiguration of the boundaries of international development cooperation and the insertion of multiple actors, including universities and their transnational partnerships (King, 2008; Obamba and Mwema, 2009). As part of this evolving landscape, a growing body of recent policy instruments in Africa have articulated the significance and potentials of this emerging interface between higher education and international development (NEPAD, 2005; African Union, 2008; Teferra, 2010). In September 2010, the AAU and European University Association (EUA) launched a joint White Paper on Africa-Europe Higher Education Cooperation for Development. Significantly, the White Paper draws attention to 'the evolving and increasingly important overlap between the internationalization agenda of universities and their role as actors in development cooperation' (EAU/AAU, 2010, 6).

The evidence seems to suggest that the OECD and other multilateral agencies had predominantly preceded the World Bank in articulating the 
'partnership paradigm' in education development policy. The World Bank juggernaut did not capture the 'global partnership' discourse in any substantial manner within its education policy regimes until relatively recently. For many decades, the underlying ethos of the Bank's policy regimes has been predominantly monocentric and asymmetrical (Samoff and Carrol, 2004). But this approach has been abandoned. Salmi et al. (2010) have captured this recent shift in Bank education policy from monopolarity to multipolarity, observing that to promote sustainable and mutually beneficial approaches to higher education, the World Bank works increasingly in partnership with other multilateral agencies ... and with international and regional associations of universities' (ibid., 111). Similarly, the Bank's current Africa Regional Strategy (World Bank, 2011b) demonstrates the growing centrality of multilevel partnership:

The main instrument for implementing this strategy is partnership- with African Society, governments, the private sector, universities, policy research institutions, and other development actors. We will deepen cooperation with a wider range of partners at the national, regional and global levels, stepping back where others have comparative advantage and leading where we are well placed to do so. (ibid., 31)

The Bank's current Education Strategy 2020 demonstrates the Bank's unprecedented and decisive shift from its traditional 'lone-ranger' approach and the herald of the newly emergent partnership approach to education and development policy (World Bank, 2011a). The Strategy 2020 is anchored on the principles of global partnership, harmonization, and pluralism in international development cooperation, which the Bank has drawn directly from the leaves of the Paris Declaration on Aid Effectiveness (OECD, 2005) and the Accra Plan of Action (2008). The Strategy emphasizes the growing multiplicity of stakeholders in education policymaking and funding as well as the importance of mobilizing and harmonizing collaborative global and national efforts (World Bank, 2011a, 23). In this regard, the Strategy concedes that 'the global challenge of improving the quality of education is immense; it requires collaboration and alignment of interests [and resources] among many actors' (ibid., 70). This most recent document demonstrates the Bank's transformation from a monopolistic policy actor to an increasingly collaborative operator that recognizes the astonishing plurality and complexity of the education and development policy landscape (see also Obamba, 2011, 170-175).

\section{The 'Science-Technology-Innovation' Paradigm}

The knowledge-based economy provoked the emergence of innovation systems as a dynamic model for organizing and analysing the components, processes, 
and outcomes of sustainable development (OECD, 1996b). The 'innovation system' is seen as one of the four pillars of the knowledge economy (OECD, 1997). An innovation system is defined as 'all the important economic, social, political, organizational, and other factors that influence the development, diffusion, and use of innovations' (Edquist, 2001, 2). The idea of 'innovations systems' emerged and gained increasing prominence within science, technology, and entrepreneurship studies during 1980s and 1990s (Edquist, 2001; Godin, 2007); however, it did not command significant global influence within development policy and development economics until the publication of the seminal OECD report National Innovation Systems (OECD, 1997). The innovation systems approach has had a widespread and tremendous impact in diverse areas, such as science, development policy, technology, macroeconomics, and scientific research (OECD, 1997; Edquist, 2001; Chen and Dahlman, 2006; Godin 2007).

Within the World Bank, however, evidence suggests that the discourse and support for innovation systems is a relatively recent phenomenon, despite the Bank's historical interest in promoting Science and Technology (Watson et al., 2003, 1) and its recent tremendous focus on the knowledge-based economy (World Bank, 2002a). Several analyses emerging within the Bank during the 1990s and early 2000s have criticized the Bank for lacking a systematic policy framework and organizational capabilities for promoting S\&T, especially with respect to higher education and in developing countries (Dahlman, 1995, 10-11; Watson et al., 2003). A recent review of Bank lending practice reports that the Bank lent USD 8.6 billion to support science and technology (S\&T) through 647 projects between 1980 and 2004. However, the report observed that 'of overall Bank lending ... only 1 in about 50 projects is principally concerned with improving science and technology' (Crawford et al., 2006, 10).

Another significant Bank Policy Research Paper (Watson et al., 2003) criticized the Bank's 'historical legacy of ad hoc promotion of science and technology' (ibid., 26). The Paper argued that 'attempts to raise S\&T among clients have not always been sustained or systematic ... and these have never been articulated within a comprehensive policy or plan for improving science and technology across the board' (ibid., 1). Bank support for S\&T in the tertiary education sector has been limited for decades and has predominantly been targeted at middle-income countries (Watson et al., 2003). The authors emphasized that 'the challenge for the Bank is to make S\&T a part of tertiary education reform for a broader spectrum of clients [read developing countries]' (ibid., 27).

However, the global landscape has shifted dramatically in recent years and the Bank has moved to re-invent and reconsolidate itself. In July 2002, the World Bank issued a major report entitled Strategic Approaches to Science 
and Technology in Development, which reviewed the Bank's experience and capabilities in the field of STI capacity development (World Bank, 2002b). This radical report emphasized that 'the World Bank should be ready to play an appropriate role along with partner agencies in responding to the heightened demand to S\&T-related services in the new environment of S\&T prioritization' (ibid., v). The Bank's response came in February 2007, when it partnered with multiple agencies to convene the first Global Forum on Science Technology and Innovation to discuss strategies, programmes, policies for building STI capacity to promote sustainable growth and poverty reduction in developing countries (World Bank, 2007). The Bank articulated a broader and more practical contextual formulation of STI capacity building:

STI capacity building is about building the technical, vocational, engineering, entrepreneurial, managerial, and scientific capacity to solve each country's pressing social and economic problems, transform their societies, and have a positive impact on the standards of living and quality of life of the poorest strata of society. (World Bank 2007, x)

Anchored on this new broad conceptualization, the Global Forum emphasized that capacity building for STI can no longer be viewed as a luxury preserved primarily for the wealthier countries. Instead, the report stated that 'if developing countries hoped to prosper in the knowledge economy ... STI capacity building is an absolute necessity' (ibid., 1). A major resolution of the Global Forum was that 'STI capacity building is not a diversion from poverty reduction and the MDG's; it is an essential tool for achieving the MDG's and reducing poverty' (World Bank, 2007, 6). But in 2010 the Bank made the most robust response to its new knowledge mandate by publishing its groundbreaking knowledge strategy paper Transforming the Bank's Knowledge Agenda (World Bank, 2010). This strategic framework paper is aimed at expanding the Bank's knowledge services and defining a more systematic approach to its role as a leading producer, customizer, and connector of knowledge in a rapidly changing global environment. In 2008, the African Development Bank issued an ambitious Strategy for Higher Education Science and Technology that was aimed to accelerate sustainable economic growth through capacity development and strengthening in science and technology in African countries. The Strategy demonstrates the growing prioritization of science and technology capacity in contemporary African development policy and discourse (AfDB, 2008, v). A recent World Bank report (World Bank, 2009b) makes a remarkable conclusion that illustrates the importance of S\&T in Africa's development:

A more knowledge-intensive approach to development is emerging as an attractive option for many African countries. In fact, it is possibly the 
only route that could permit sustained, outward-oriented development. (World Bank, 2009b, xxii)

\section{Multisectoral and Systems Approaches}

Another unprecedented transformation within the Bank's education strategy is the natural demise of the fragmented 'sectoral' perspective and the emergence of the holistic systems approach to education policy and funding (Salmi et al., 2010, 110; Obamba, 2011). The holistic perspective emphasizes that a country's entire education establishment should be treated as an integrated entity in matters related to policy and investment. It also means that the education sector should also be viewed in terms of its complex relationships and interactions with other economic and social sectors, rather than as a singular isolated entity (World Bank, 2005). This new policy paradigm was first articulated in the Education Sector Strategy Paper for 1999 (World Bank, 1999a). The Paper observed that 'Bank staff now look more at education as an integrated system; one part of which cannot function well if another part is ailing' (ibid., 24). The next Bank document, Education Sector Strategy Update 2005, also captured and further articulated the holistic approach (World Bank, 2005).

A more detailed and broader conceptualization of this holistic and integrated policy paradigm is demonstrated in the Bank's Education Strategy 2020 (World Bank, 2011a). The current Strategy, appropriately titled Learning for All, is a remarkably radical and unprecedented document in the entire 50 -year history of education investment and policymaking at the Bank. First, Strategy 2020 radically pushes the boundaries of the 'holistic' approach and embraces the more dynamic and comprehensive systems approach to education sector policy and development. In this broader approach, the 'education system' is defined as 'all learning opportunities in a given society, whether within or outside the formal education institutions ... and consists of all parties who participate in the provision, financing, and use of learning services' (World Bank, 2011a, 29). This broad-based conceptualization of education clearly demonstrates the emergence of a pluralistic and multi-stakeholder perspective to the education sector, which also emphasizes partnership and collaborative efforts. This new broad approach not only removes the classical fragmentations between various sectors of the education establishment, but, more importantly, also emphasizes the blurring boundaries between the formal-informal and public-private dichotomies that have shaped educational investment, analysis, and policy for decades. In fact, the Strategy has made this transition categorically clear:

Past education strategies of the World Bank have focused very much on the formal schools that are funded and/or operated by governments. 
The new strategy explicitly recognizes that learning opportunities go beyond those offered by the public sector, as well as beyond traditional formal programs. (ibid., 30)

\section{From 'Education for All' to 'Learning for All': Convergence and Continuity}

In its current Education Sector Strategy 2020, the Bank's dominant discourse has dramatically shifted from the well-known 'Education for All' to 'Learning for All'. The shift in discourse may seem insignificant, but on a closer look it represents a more fundamental transformation in the Bank's evolving perspectives and thinking. First, as we have already discussed, the Bank's Strategy 2020 seeks to remove the fragmentations associated with the public-private and formal-informal dichotomies and to emphasize greater convergence and continuity in education policy. The second significant feature of the new Education Strategy 2020 is its unprecedented and multidimensional perspectives on education phenomenon.

The Bank acknowledges that tremendous gains have been made in most countries in terms of greater enrolment levels and gender equity in access, thanks to significant investments and initiatives including Education for All (World Bank, 2011a, 14). Unfortunately, the World Bank decries an emerging scenario of more schooling and little learning especially in developing countries. The paper observes that 'for too many students, more schooling has not resulted in greater learning' (ibid., 17). Unlike previous Bank Strategy Papers, therefore, the core focus of the Strategy is on learning outcomes and lifelong learning, rather than the traditional preoccupation with gross enrolment statistics or the years students spend sitting in classrooms. The focus also transcends beyond the learning experiences that take place within the formal schooling systems at distinct socio-biographic stages. Instead the new Strategy 'is built on the premise that people learn throughout life, not simply during the years they spend in formal schooling' (World Bank, 2011a, 25). The new fundamental emphasis is on what people really learn in terms of knowledge, skills, and competencies both within and outside the formal schooling systems and throughout their lives (ibid., 3-4). The Bank's new pillars of Strategy 2020 are: 'invest early. Invest smartly. Invest for all'. On these and other major grounds, the Strategy 2020 is undoubtedly a revolutionary and unprecedented Bank document. The traditional multiple fragmentations along primary-secondary-tertiary, public-private, and formalinformal segments have all been decisively deconstructed and redefined. Even the Bank's traditionally favourite rate of return empirical analysis no longer occupies a central position in the discourse of the new Education Strategy. 


\section{Conclusions}

This paper set out to analyse the production and trajectories of various theoretical and ideological paradigms that have shaped the World Bank's priorities and approach to education and development policy in sub-Saharan Africa over the last four decades. The paper illustrates that the World Bank has historically captured and selectively propagated multiple and often shifting theoretical regimes to formulate its education programmes and policy priorities in developing countries. In particular, the paper suggests that the Bank had utilized a selective and partial set of empirical analyses and interpretations of the human capital theory and 'rates of return' arithmetic to reproduce a deeply fragmented and asymmetric education policy landscape, one that valorized basic education while devaluing and even devastating higher education in subSaharan Africa. This polarizing policy paradigm persisted until late 1990s and promoted the notion that basic primary education was a more economically productive public investment compared with university education. Since 2000, however, the Bank has dramatically abandoned these analyses and discourses. Through its growing body of analyses and policy instruments since 2000, the Bank has demonstrated a new emphasis on the knowledge-based development paradigm, whereby the creation, adaptation, and use of knowledge is the driver of sustained economic growth and poverty reduction for all societies worldwide. After decades of decay and systematic marginalization, this new global knowledge dispensation provides a vital window of opportunity for sub-Saharan Africa to stagger to its feet and steeply redefine its trajectory in the dynamic and unequal global knowledge calculus.

The paper has illuminated some of the most recent and significant transformations in World Bank education sector policy and thinking. These include the shift from Education for All to Learning for All; the new focus on learning outcomes and life-long learning as opposed to gross enrolments; and the progressive attempts to bridge and redefine the dichotomies between public-private and formal-informal in educational analysis and policymaking. The paper has examined two distinctive and important phenomena that have co-evolved as components of the knowledge-based economy in more recent decades. The first phenomenon is the 'global partnership' paradigm, which is prominently manifested both in the field of international development and within higher education. The significance of the partnership paradigm resides in the fact that it has widened the boundaries of international development cooperation to include multiple actors and activities, including universities. The second significant epoch that emerged alongside the knowledge-based economy is the innovation systems' or 'science-technology-innovation' paradigm.

The importance of the 'innovation systems' and the 'global partnership' paradigms is that they transcend traditional boundaries and encompass the 
broadest spectrum of economic actors, activities, and relationships, thereby making collaborative scientific and development efforts more inclusive, more effective, and more relevant to diverse practical contexts. The paper captured the World Bank's recent emphasis that capacity building for ScienceTechnology-Innovation is an absolute necessity for all countries, especially for poverty-reduction in developing countries. Although the partnership paradigm and the innovation systems approach both provide fresh perspectives and critiques in support of boundary-spanning interactions between developing and the developed world, the embedded patterns of asymmetry and dependency between the global North and the South could persist or further deepen if the current unequal framework of the global knowledge-based economy and the organizational architecture of knowledge production are not radically reconfigured to become more truly equitable and inclusive.

\section{References}

AfDB. (2008) Strategy for Higher Education Science and Technology, Tunis: African Development Bank.

African Union. (2008) The AU/NEPAD African Action Plan, Addis Ababa: The African Union.

Aina, T.A. (2010) 'Beyond reforms: the politics of higher education transformation in Africa', African Studies Review 53(1): 21-40.

Banya, K. and Elu, J. (2001) 'The World Bank and financing higher education in sub-Saharan Africa', Higher Education 42(1): 1-34.

Basset, R.M. and Maldonado-Maldonado, A. (eds.) (2010) International Organizations and Higher Education Policy, New York and London: Routledge.

Becker, G.S. (1962) 'Investment in human capital: a theoretical analysis', The Journal of Political Economy 70(5 pt II-Investment in Human Beings): 9-49.

Blaug, M. (1965) 'Rate of return on investment in education in Britain', The Manchester School 33(3): 205-251.

Blaug, M. (1967) 'A cost benefit approach to educational planning in developing countries', Report No. EC-157. Washington DC: World Bank.

Bloom, D., Canning, D. and Chan, K. (2005) Higher Education and Economic Development in Africa., Washington DC: Human Development Sector, Africa Region, World Bank.

Carnegie Commission on Higher Education. (1973) Higher Education: Who Pays? Who Benefits? Who Should Pay? New York: McGraw-Hill.

Chen, H.C.D. and Dahlman, C.J. (2006) 'The knowledge economy, KAM methodology, and World Bank operations', Discussion Paper, Washington DC: The World Bank.

Collins, C.S. and Rhoads, R.A. (2010) 'The World Bank, support for universities, and asymmetrical power relations in international development', Higher Education 59(2): 181-205.

Crawford, M.F., Yammal, C.C., Yang, H. and Brezenoff, R.L. (2006) 'Review of World Bank lending for science and technology 1980-2004', STI Discussion Paper Series, Washington DC: World Bank.

Dahlman, C. (1995) 'Technology, development and role of the World Bank', HRO Working Paper Series, Washington DC: World Bank.

Daniba, A. (1991) The World Conference on Education For All and Africa's Expectations, pp. 8-11 Dakar: UNESCO. 
Drake, P., Ludden, D., Nzongola-Ntalaja, G., Patel, S. and Sevtsova, L. (2000) 'International scholarly collaboration: lessons from the past', Inter-regional Working Group on International Scholarly Collaboration, New York: The Social Science Research Council.

EAU/AAU. (2010) Africa-Europe Higher Education Cooperation for Development: Meeting Regional and Global Challenges, Brussels: European University Association- African Association of Universities.

Edquist, C. (2001) 'The innovation systems approach and innovation policy: an account of the state of the art', Paper presented at the DRUID Conference; 12-15 June, Aalborg, Denmark.

Godin, B. (2007) 'National innovation system: the systems approach in historical perspective', Working Paper No. 36, Montreal: History and Sociology of STI Statistics.

Harbison, F. and Myers, C. (1964) Education, Manpower, and Economic Growth, New York: McGraw Hill.

Heyneman, S.P. (2003) 'The history and problems in the making of education policy at the World Bank 1960-2000', International Journal of Educational Development 23(3): 315-337.

Hinchliffe, K. (1985) 'Higher education in Sub-Saharan Africa', Discussion Paper No. EDT 3, Washington DC: The World Bank.

King, K. (2008) 'The promise and perils of partnerships', NORRAG News 41: 7-11.

Kinser, K. and Green, M. (2009) The Power of Partnerships: A Transatlantic Dialogue, Washington DC: American Council on Education.

NEPAD. (2005) 'Renewal of higher education in Africa: Report of AU/NEPAD workshop', 27-28 October, Johannesburg.

OAU. (1980) The Lagos Plan of Action for the Economic Development of African 1980-2000, Addis Ababa: Organization of African Unity.

Obamba, M.O. (2011) 'Betwixt public-private: market trajectories and governance restructuring in Kenya's Universities', unpublished Doctoral Dissertation, Leeds Metropolitan University.

Obamba, M.O. and Mwema, J.K. (2009) 'Symmetry and asymmetry: new contours, paradigms, and politics in African Academic Partnerships', Higher Education Policy 22(3): 349-371.

OECD. (1996a) The Knowledge Based Economy, Paris: OECD.

OECD. (1996b) Shaping the 21st Century: The Contributions of Development Cooperation, Paris: OECD.

OECD. (1997) National Innovation Systems, Paris: OECD.

OECD. (2005) The Paris Declaration on Aid Effectiveness, Paris: OECD.

OECD. (2008) Accra Agenda for Action, Paris: OECD.

Psacharopoulos, G. (1973) Returns to Education: An International Comparison, Elsevier: Amsterdam.

Psacharopoulos, G. (1980) 'Higher education in developing countries: a cost-benefit analysis world', Bank Staff. Working Papers 440. Washington DC.

Psacharopoulos, G. (1981) 'Returns to education: an updated international comparison', Comparative Education 17(3): 321-341.

Robbins Committee. (1963) Higher Education: Report of a Committee under the Chairmanship of Lord Robbins, London: Her Majesty's Stationery Office (HMSO).

Salmi, J., Hopper, R. and Basset, R.M. (2010) 'Transforming Higher Education in Developing Countries: The Role of the World Bank', in R.M. Basset and A. Maldonado-Maldonado (eds.) International Organizations and Higher Education Policy: Thinking Globally, Acting Locally? New York and London: Routledge, pp. 99-112.

Saint, W. (1992) Universities in Africa: Strategies for Stabilization and Revitalization, Washington DC: World Bank.

Higher Education Policy 201326 
Samoff, J. and Carrol, B. (2004) 'The promise of partnership and continuities of dependence: external support to higher education in Africa', African Studies Review 47(1): 67-199.

Schultz, T.W. (1962) 'Reflections on investment in man', The Journal of Political Economy 70 (5 past II-Investment in Human Beings): 1-8.

Sidhu, R. (2007) 'GATS and the new developmentalism: governing transnational education', Comparative Education Review 51(2): 203-227.

Teferra, D. (2010) 'Higher Education in Africa: The Dynamics of International Partnerships and Interventions', in R.M. Basset and A. Maldonado-Maldonado (eds.) International Organizations and Higher Education Policy: Thinking Globally, Acting Locally? New York and London: Routledge, pp. 155-173.

Thias, H.H. and Carnoy, M. (1972) 'Cost benefit analysis in education: a case study of Kenya', Occasional Paper No. 14, Washington DC: The World Bank.

UNESCO. (1961) Conference of Ministers of Education of Independent States in Africa 1961. Addis Ababa: UNESCO/Organization of African Unity.

UNESCO. (1990) World Declaration on Education for All: A Framework of Action on Meeting Basic Learning Needs., UNESCO: New York.

United Nations. (1979) The Vienna Program of Action on Science and Technology for Development. New York: United Nations.

Vawda, A.Y., Moock, P., Gittinger, J.P. and Patrinos, H.A. (2001) 'Economic analysis of World Bank education projects and project outcomes', Working Paper, Washington DC: World Bank.

Velho, L. (2002) 'North-South collaboration and systems of innovation', International Journal of Technology Management 1(3): 171-181.

Watson, R., Crawford, M. and Farley, S. (2003) 'Strategic approaches to science and technology in development', Policy Research Working Paper No. 3026, Washington DC: World Bank.

Woodhall, M. (2008) 'Funding higher education: the contribution of economic thinking to debate and policy development', Education Working Paper Series No. 8, Washington: World Bank.

World Bank. (1963) Proposed Bank/IDA Policies in the Field of Education, Washington DC: World Bank.

World Bank. (1970) Lending in Education, Washington DC: World Bank.

World Bank. (1971) Education Sector Working Paper, Washington DC: World Bank.

World Bank. (1974) Education Sector Working Paper, Washington DC: World Bank.

World Bank. (1980) Education Sector Policy Paper, Washington DC: World Bank.

World Bank. (1986) Financing Education in Developing Countries: An Exploration of Policy Options, Washington DC: World Bank.

World Bank. (1988) Education in Sub-Saharan Africa: Policies for Adjustment, Revitalization, Expansion, Washington DC: World Bank.

World Bank. (1994) Higher Education in Africa: The Lessons of Experience, Washington DC: World Bank.

World Bank. (1995) Priorities and Strategies for Education: A World Bank Review, Washington DC: World Bank.

World Bank. (1997) Revitalizing Higher Education in Africa: Strategy and Guidelines, Washington DC: World Bank.

World Bank. (1999a) Education Sector Strategy Paper, Washington DC: World Bank.

World Bank. (1999b) World Development Report: Knowledge for Development, New York: Oxford University Press.

World Bank. (2000) Higher Education in Developing Countries: Peril and Promise, The Task Force on Higher Education and Society, Washington DC: The World Bank.

World Bank. (2002a) Constructing Knowledge Societies: New Challenges for Tertiary Education, Washington DC: World Bank. 
World Bank. (2002b) 'Strategic approaches to science and technology in development', Report to the World Bank Board of Directors, Washington DC: World Bank.

World Bank. (2005) Education Sector Strategy Update, Washington DC: World Bank.

World Bank. (2007) Science, Technology, and Innovation: Capacity Building for Sustainable Growth and Poverty Reduction, Washington DC: World Bank.

World Bank. (2009a) Education Year in Review 2009, Washington DC: The World Bank.

World Bank. (2009b) Accelerating Catch-up: Tertiary Education for Growth in Sub-Saharan Africa, Washington DC: The World Bank.

World Bank. (2010) Transforming the Bank's Knowledge Agenda: A Framework for Action, Washington DC: World Bank.

World Bank. (2011a) Education Sector Strategy 2020: Learning for All, Washington DC: World Bank.

World Bank. (2011b) Africa's Future and World Bank's Support to it: Africa Regional Strategy, Washington DC: The World Bank. 